\title{
Особливості реабілітаційних заходів для дітей шкільного віку із зони конфлікту на сході України
}

\author{
УДК 159.922.6
}

\section{І. С. Лебець, В. О. Диннік, Т. М. Матковська, Т. П. Костенко, І. С. Миронюк, Л. М. Овсяннікова, Н. В. Медведовська}

Національна академія медичних наук України (НАМН України), Державна установа «Інститут охорони здоров'я дітей та підлітків НАМН України», Харків, Україна ДВНЗ «Ужгородський національний університет», Ужгород, Україна

Резюме. Мета. На підставі визначених тенденцій змін стану здоров'я дітей шкільного віку із зони конфлікту на сході України, психологічних особливостей даного контингенту, окреслити принципи їх реабілітації у межах медико-психологічного супроводу для зменшення числа дітей із психосоматичними розладами, психологічними відхиленнями в умовах дії посттравматичного стресу різного рівня. Матеріали та методи. Проведено клініко-параклінічне обстеження 286 дітей шкільного віку, які мешкають на території Донецької і Луганської областей, та переселенців з цих зон. Для кількісного визначення рівня стресу використовували кардіоінтервалографію з подальшим аналізом варіабельності серцевого ритму. Психологічні особливості визначали з використанням методик: багатовимірної оцінки дитячої тривожності, внутрішньої картини здоров'я, тесту М. Люшера. Інтенсивність стрес-реалізуючих систем оцінювали із урахуванням показників: кортизолу, адреналіну, норадреналіну, продуктів пол; стрес-лімітуючих систем: серотоніну, мелотоніну, відновленому глутатіону, активності глутатіонпероксидази і супероксиддисмутази. Результати. У роботі наведено виявлені в стані здоров'я дітей особливості, характер психологічних відхилень із урахуванням дії психоемоційного стресу. Подано пропозиції стосовно медико-психологічного супроводу та реабілітації даного контингенту. Висновки. Більшість дітей із зони збройного конфлікту має підвищений рівень емоційного напруження, що провокує активацію стрес-регулюючих систем. Зазначене впливає на формування психологічних відхилень та особливостей у стані здоров'я, що потребує проведення реабілітаційних заходів задля попередження розвитку та виникнення загострень патології різних систем організму.

Ключові слова: діти із зони військового конфлікту, психосоматичне здоров'я, психологічні відхилення, реабілітація, медико-психологічний супровід.

\section{Peculiarities of rehabilitative measures for school children from the conflict zone in eastern Ukraine}

I. S. Lebets, V. O. Dynnik, T. M. Matkovska, T. P. Kostenko, I. S. Myroniuk, L. M. Ovsiannikova, N. V. Medvedovska

National Academy of Medical Sciences of Ukraine (NAMS of Ukraine), State Institution «Institute of Child and Adolescent Health of the NAMS of Ukraine», Kharkiv, Ukraine Uzhhorod National University, Uzhhorod, Ukraine

Abstract. Objective. Based on the identified trends in the health of school-age children from the conflict zone, in eastern Ukraine, the psychological characteristics of this contingent, to outline the principles of their rehabilitation within medico-psychological support to reduce the number of children with psychosomatic disorders, psychological deviations under the conditions of posttraumatic stress of different level. Materials and methods. Clinical and paraclinical examination of 286 schoolchildren living in the Donetsk and Luhansk regions, and displaced people from these zones was carried out. To quantify the level of stress, cardiointervalography was used, followed by an analysis of heart rate variability. Psychological characteristics were determined using the following 
methods: multidimensional assessment of child anxiety, internal health picture, M. Lusher test. The intensity of stress-implementing systems was evaluated taking into account the indice of: cortisol, adrenaline, noradrenalin, and lipid peroxidation products; stress-limiting systems: serotonin, melatonin, reduced glutathione, glutathione peroxides and superoxide dismutase activity. Results. The paper presents the revealed features of the children's health status, the nature of psychological deviations with account for the effects of psychoemotional stress. Suggestions are made on the advisability of medical and psychological support and rehabilitation of this contingent. Conclusions. Most children from the military conflict zone have an increased level of emotional stress, which provokes the activation of stress-regulating systems. The above affects the formation of psychological deviations and peculiarities of health status, which requires rehabilitation measures to prevent the development and occurrence of exacerbations of the pathology of various body systems.

Keywords: children from the military conflict zone, psychosomatic health, psychological deviations, rehabilitation, medical and psychological support.

Постановка проблеми. Важливою характеристикою сучасного світу є глобальні міграційні процеси, інтенсивність яких постійно зростає. Їх особливою складовою $€$ так звана внутрішня міграція, що включає міграцію осіб, переміщених всередині країни. Цей феномен $€$ досить складним, проблемним і багатогранним процесом [2, 7]. На сьогодні проблема дітей, які пережили той чи інший травматичний досвід, стає однією з центральних у дитячій психіатрії [3-5]. Дитина, котра пережила військові та пов'язані з ними негативні події, відчуває ті самі почуття, що і дорослі - страх повторення подій, руйнування ілюзії справедливості світу, безпорадність. Ступінь дезадаптації особистості внаслідок стресорного впливу залежить від системи психологічного захисту. Аналіз психологічних проблем постраждалих від стресу показує, що вони носять комплексний характер, який включає основні сфери особистості: емоційну, когнітивну, поведінкову, мотиваційно-потребову, комунікативну $[1,9,10$, 12]. Відомо, що реакції на травматичні події залежать від віку, стадії розвитку дітей, а також від уміння цих дітей застосовувати різні засоби для свого порятунку. Діти дошкільного віку часто демонструють регресивну реакцію. Значно змінюються після стресів діти молодшого шкільного віку. Вони стають дратівливими, грубими, у них з'являються скарги на погане самопочуття без функціональних і органічних порушень. Особливі труднощі переживають діти підліткового віку, який $\epsilon$ важливим етапом у формуванні й розвитку ідентичності $[6,8,11]$.

Зв'язок роботи 3 важливими науковими програмами або практичними завданнями. Робота виконана в рамках державної бюджетної тематики НАМН України, а саме прикладної НДР «Дослідити стан здоров'я дітей шкільного віку із зони антитерористичної операції та розробити систему медико-психологічного супроводу» (номер держреєстрації 0116U003034, термін виконання 2016-2018рр.), яка виконувалася в
ДУ «Інститут охорони здоров'я дітей та підлітків НАМН України» (ДУ «ІОЗДП НАМН України»).

Мета дослідження: на підставі визначених тенденцій змін стану здоров'я дітей шкільного віку із зони конфрлікту на сході України, психологічних особливостей даного контингенту, окреслити принципи їх реабілітації у межах медикопсихологічного супроводу для зменшення числа дітей із психосоматичними розладами, психологічними відхиленнями в умовах дії посттравматичного стресу різного рівня.

Методи і організація дослідження. Робота базується на даних обстеження 286 дітей шкільного віку, які мешкають на території Донецької та Луганської областей, а також їх однолітків, які вимушені були покинути зазначену місцевість через військові дії та проживати в інших регіонах України як біженці. На час дослідження вони знаходилися на стаціонарному лікуванні в ДУ «ІОЗДП НАМН України». Для кількісного визначення рівня стресу застосовували кардіоінтервалографрію з подальшим аналізом варіабельності серцевого ритму. Для встановлення психологічних особливостей використовувалась психологічна методика багатовимірної оцінки дитячої тривожності (БОДТ). Особливості уявлень про власне здоров'я вивчали за допомогою методики визначення внутрішньої картини здоров'я (ВКЗ), для виявлення емоційних особливостей особистості використовували тест вибору кольору М. Люшера. Інтенсивність стрес-реалізуючих систем оцінювали 3 урахуванням показників: кортизолу, адреналіну, норадреналіну, продуктів ПОЛ. Для визначення стану стрес-лімітуючих систем визначали: серотонін, мелотонін, відновлений глутатіон, активність глутатіонпероксидази і супероксиддисмутази. У всіх хворих ретельно аналізували соматичне та психічне здоров'я скарги, клінічні прояви, додаткові параклінічні дослідження. Проведене висококваліфріковане дослідження в умовах багатопрофрільної лікувальної й наукової установи дозволило детально 
оцінити стан здоров'я зазначеного контингенту та визначити головні напрями щодо його медикопсихологічного спостереження й оздоровлення як на стаціонарному, так і поліклінічному етапах.

Результати дослідження та їх обговорення. За даними кардіоінтервалографрії у більшості дітей із зони збройного конфрлікту було визначено ознаки перенесеного стресу різного рівня вираженості. Загалом середній та високий ступінь стресу встановлено в 33 \% осіб. Дані психологічних методик (тест Люшера) підтверджували вищезазначене. При цьому не було виявлено відмінностей за частотою наявності чи різного рівня стресу між постійними мешканцями зони конфрлікту та переселенцями.

Аналіз біохімічних показників свідчив про те, що у дітей із зони конфрлікту перенесений стрес провокує активацію стрес-регулюючих систем, вираженість якої залежить від інтенсивності стресу. Особлива роль у цих процесах відводиться кортизолу, дієновим кон'югатам, ТБК-активним продуктам, відновленому глутатіону, мелатоніну. У дітей-переселенців реєструвався більш високий рівень окремих показників стрес-реалізуючої системи (адреналін) порівняно зі школярами із зони бойових дій, що свідчило про вплив на організм дитини зміни місця прживання, як додаткового фактора стресу. Встановлено, що найбільш часто стрес високої сили у дівчаток виявляється при неправильному старті пубертату, асоційованому з посиленням роботи кори надниркових залоз. Стреси середньої й низької сили при фрізіологічному пубертаті, випередженні та ретардації статевого розвитку можуть свідчити про напруження в системі адаптації.

Отримані дані не викликають сумніву щодо розвитку стресових подій в організмі дітей шкільного віку різної статі як постійних мешканців зони конфлікту, так і переселенців, які залишили цю місцевість та переїхали в інші регіони України. Слід зазначити, що інтенсивність стресу більшою мірою впливає на відхилення вивчених показників у хлопців, зачіпаючи не тільки компоненти АOC і ПОЛ, але й і зміни стрес-реалізуючих гормонів, що може сприяти прогресуванню клініко-психологічних проявів стресу. Слід відмітити, що в жіночому організмі еволюційно запрограмований високий антирадикальний захист, який забезпечується значною активністю антиоксидантних фрерментів, зокрема СОД, і жіночими статевими гормонами.

Дані спостережень свідчили про те, що практично у всіх пацієнтів реєструються соматичні скарги (97,6 \%). При цьому в 24,4 \% вони були дещо надмірними. Більше половини пацієнтів висували щоденні скарги на різноманітні больові відчуття, що заважають їх функціонуванню та буденній діяльності. Більшість із них пов'язували погіршення стану здоров'я 3 психоемоційним навантаженням. За частотою перші позиції займали астеноневротичні та гастроентерологічні скарги. Особливо у цьому відношенні виділялися діти-переселенці. У структурі соматичної патології провідне місце займали розлади з боку органів травлення (52,7 \%), серед яких переважали фрункціональні порушення. Органічна патологія (гастродуоденіт, холецистит) виявлялася в $23,0 \%$ дітей. Захворювання органів кровообігу зареєстровано в 29,8 \% пацієнтів, суглобів $31,3 \%$. Проте частота уражень зазначених й інших систем організму суттєво не відрізнялась від основних показників по Україні.

Серед виявлених ендокринопатій провідне місце займав цукровий діабет. Відсоток дітей, хворих на цукровий діабет, - мешканців зони збройного конфлікту, достовірно перевищував показники дітей м. Харкова. Друге місце в структурі ендокринної патології належить патології щитоподібної залози, частота якої теж була значно вищою в осіб зони збройного конфлікту, порівняно з мешканцями м. Харкова. Переважали дифузний нетоксичний зоб та автоімунний тиреоїдит. Необхідно відмітити, що близько третини (31,5 \%) дітей мали по декілька ендокринологічних захворювань.

За даними дослідження встановлено, що статевий розвиток, який відповідав хронологічному (паспортному) віку, реєструвався у 70,4 \% всіх обстежених дівчат. Передчасний статевий розвиток (поява вторинних статевих ознак до 8 років) зустрічався в 15,8 \%, що в 1,7 раза перевищує популяційні показники. Можна припустити, що перебування в зоні військового конфлікту стало поштовхом до активації гіпоталамо-гіпофрізарногонадного комплексу і початку несвоєчасного статевого розвитку у цього контингенту дітей. Прискорення темпів статевого розвитку (коли бал вторинних статевих ознак випереджав нормальні значення на 2 роки і більше при своєчасному початку пубертату) виявили у 29,4 \% дівчаток, що суттєво не відрізняється від аналогічних даних школярок м. Харкова. Звертало на себе увагу, що у 14,3 \% дівчат-підлітків реєструвалося відставання темпів статевого розвитку; виявлений відсоток у 7,5 раза перевищував показник у харківському регіоні. Оцінка статевого розвитку виявила, що у частини дітей порушувалася черговість появи вторинних статевих ознак, і статевий розвиток починався з ініціації вторинного оволосіння (шлях «pubarche»), що може бути предиктором фрормування нейроендокринної патології у майбутньому. Становлення менструальної функ- 
ції $€$ інтегрованим показником стану системи репродукції. Середній вік появи менархе становив 12,5 \pm 0,14 року, що відповідає популяційним показникам і не має суттєвої різниці з віком менархе розвинутих європейських країн. Нормальний менструальний цикл визначався більше ніж у половини дівчат $(53,7$ \%). Водночас, порушення менструальної фрункції було зареєстровано у $46,3 \%$, що значно частіше, ніж у популяції.

В ході скринінгового обстеження у всіх пацієнтів виявлялися підвищені показники рівня тривоги та депресії, деякі 3 них навіть відмовилися від психіатричного обстеження та психологічних консультацій. Звертало на себе увагу посилення проявів енурезу (24,4 \%), нав'язливих дій $(27,3 \%)$, тиків $(23,6 \%)$, заїкання $(25,6 \%)$, диспное $(22,4$ \%). Переважали тривожні розлади, короткочасна та довготривала невротична i депресивна реакції. Психіатр найчастіше виявляв такі скарги: головний біль $(96,8$ \%), порушення сну $(96,8 \%)$, дратівливість $(68,5 \%)$, когнітивні порушення (51,0\%), стомлюваність $(42,4 \%)$, агресія (36,8 \%), нудьга (29,6 \%), фробії $(28,8 \%)$, погіршення працездатності $(28,0 \%)$, вегетативні порушення $(24,4 \%)$, апатія $(23,2 \%)$, втрата відчуття задоволення $(23,4 \%)$.

Розглядаючи статевий аспект симптоматики, слід зазначити, що більшість симптомів зустрічалися з однаковою частотою як у хлопців, так і дівчат.

Для всіх дітей було характерне погіршення успішності в школі, дратівливість, пригнічений настрій, у більшості - гіпоактивність, легке утримання афекту у виразі обличчя, надмірна плаксивість, соціальна самоізоляція.

Симптом відчуття провини реєстровано у $60,0 \%$ дітей. У 70,4 \% обстежених виявлено зниження самооцінки. При цьому 27,6 \% дітей вказували на одну важливу проблему, вирішити яку вони були не в силах, 36,8 \% оцінювали себе переважно негативно або мляво відповідали на запитання, що ставилися, говорили про себе зневажливо, з приниженням або недооцінювали себе, що $€$ типовим для проявів депресивного розладу.

Одним 3 патогномонічних симптомів, що часто має місце у дітей із депресією, був пригнічений настрій (100\%). Практично у всіх обстежуваних дітей $(97,6$ \%) встановлено симптом надмірної плаксивості. При цьому самі пацієнти та їх батьки констатували, що діти плачуть частіше за своїх однолітків, а іноді і без видимої причини, а 46,4 \% - майже щодня.

Гіперактивна поведінка реєструвалася у 73,6 \% обстежених, моторна загальмованість у 19,2 \%, сповільнені рухи тіла - у 7,2 \%.
Спортивна медицина і фізична реабілітація, № 1, 2020

Академічна успішність була порушена у більшості дітей шкільного віку.

Отже, для даного контингенту дітей характерна поліморфність симптомів, частково неспецифрічного характеру із переважанням у клінічних проявах астенії, емоційної лабільності, напруження, підвищеної психічної та фрізичної втомлюваності, головного болю, що ускладнює своєчасну діагностику саме депресивних розладів, початок їх формування, маскує соматичну, ендокринну патологію.

Аналіз профрілів внутрішньої картини здоров'я (ВКЗ) виявив деякі особливості у різних групах школярів. За даними тесту діти, які мешкали в зоні військових дій, були більш спрямовані на подолання хвороби та вірять в одужання, а діти-переселенці більше мають знань про здоров'я та хвороби, більш широкі уявлення щодо них і більше про них говорять. Останні більшою мірою усвідомлюють позитивний вплив стану свого здоров'я на можливості спілкування з іншими людьми. Постійні мешканці зони збройного конфрікту, діти, котрі були свідками обстрілів, бомбувань тощо менше звертають увагу на тілесні відчуття, ніж ті, що не мали подібного досвіду. Перші більш оптимістично сприймають реальність та більш бережно ставляться до свого здоров'я на відміну від групи дітей, які не були свідками бойових дій, про що свідчили дані аналізу градації «Песимістична оцінка реальності, глобалізація негативних тенденцій щодо здоров'я та руйнівна поведінка».

За даними багатомірної оцінки дитячої тривожності (БОДТ) можна акцентувати на тому, що досліджувані із зони бойових дій меншою мірою тривожні, ніж їх однолітки, які їх не бачили. Це стосувалося питань щодо відносин з однолітками, пов'язаних з навчанням, самовираженням. У цій групі відмічається більша кількість дітей, які мають зменшення психічної активності, пов'язаної з тривогою. Що стосується порівняння характеру тривожності постійних мешканців зони конфлікту і переселенців, у перших підвищена загальна тривожність зустрічалася частіше.

Враховуючи спектр виявлених відхилень щодо стану здоров'я у дітей шкільного віку із зони військового конфрлікту, обгрунтованим $€$ застосування алгоритму заходів по збереженню та підвищенню їх здоров'я, що включає організаційні, лікувальні, профрілактичні заходи на різних рівнях.

1. На рівні сімейних лікарів, підліткових терапевтів, педіатрів:

- регулярне проведення лікувально-профрілактичних заходів у межах амбулаторно-стаціонарної допомоги за місцем проживання (у разі можливостей) або у закладах тимчасово для 
цього відведених із використанням сучасних лікувально-діагностичних та реабілітаційних технологій із урахуванням особливостей фрормування функціональних розладів та патологічних станів в умовах дії психоемоційного стресу;

- інформаційне забезпечення, організація та контроль за своєчасним проведенням консультативної допомоги хворим у спеціалістів різного профрілю за місцем проживання, за необхідністю (або неможливістю) - у республіканських центрах, науково-дослідних закладах;

- проведення санітарно-освітньої роботи серед школярів, батьків, поширення знань щодо профрілактики гострої та хронічної соматичної патології, інфрекційних, паразитарних захворювань в умовах зони збройного конфллікту;

- удосконалення особистих знань лікарів стосовно розвитку та особливостей проявів соматичних, нервово-психічних розладів ін. на тлі стресових ситуацій.

2. У межах психологічної допомоги за місцем проживання (школи, поліклініки, стаціонари) - у разі можливості, або у закладах тимчасово для цього відведених (серед мігрантів) - проведення індивідуальних та групових занять щодо психологічної корекції дітей із урахуванням стану соматичного здоров'я.

Реабілітаційні заходи, спрямовані на корекцію психологічних відхилень, мають включати такий психологічний супровід зазначеного контингенту дітей та підлітків (із зони бойових дій та переселенців):

1. Психодіагностика посттравматичного стресового розладу (ПТСР) або інших психологічних відхилень. Перше інтерв'ю з дітьми та підлітками зазвичай слід проводити в присутності батьків, щоб діти могли подолати боязнь до лікаря або психолога, а надалі - окремо.

2. Психологічне консультування дітей із психологічними стресовим розладом передбачає індивідуальну та групову психоконсультативну допомогу. Для зменшення емоційного напруження, викликаного стресом, використовують емпатійне слухання.

3. Психологічне консультування батьків дітей та підлітків. Консультування спрямоване переважно на розвиток можливостей сімейної психокорекції психологічних розладів, підвищення адаптивних можливостей самих батьків.

4. Психологічне консультування та психологічна просвіта медичних працівників 3 питань супроводу дітей з психологічними стресовими розладами 3 метою безпечного та дружнього середовища в тому закладі, у тому числі й медичному, де дитина знаходиться.
5. Психокорекція спрямована на допомогу дитині стати над ситуацією, навчити її пристосовуватися до дійсності й долати психотравмуючі впливи. В її основі може бути комплекс психокорекційних методик.

Робота з близьким оточенням дітей з психологічними розладами включає в себе психологічну просвітницьку та консультативну роботу з їх батьками (чи особами, які їх замінюють), родичами та іншими дітьми, котрі перебувають із ними.

Враховуючи, що за частотою соматичної патології, її загострень суттєвих розбіжностей між школярами зони збройного конфллікту i популяційними показниками серед дітей по Україні не виявлено, принципи їх диспансерного нагляду співпадають. Водночас особливу увагу слід приділяти саме особам із високим та середнім рівнем емоційного стресу (за даними кардіоінтервалограсрії або тесту Люшера) із гастроентерологічними захворюваннями або скаргами, які можуть їх супроводжувати. Таких школярів доцільно обстежити в умовах стаціонару з обов'язковим консультуванням психіатра та психолога. В разі визначення низького рівня емоційного стресу за наявності хронічної соматичної патології або фуннціональних розладів обстеження в стаціонарі бажано проводити один раз на рік з подальшим амбулаторним наглядом педіатром, консультаціями психологом, за необхідності - психіатром, іншими спеціалістами.

За нашими даними, діагностика та лікування невротичних та психічних розладів у зазначеного контингенту ускладнюються тим фрактом, що класичні за критеріями ознаки часто маскуються іншими коморбідними станами. У зв'язку з цим особлива роль у процесі діагностики відводиться сімейним лікарям, педіатрам, динамічному спостереженню пацієнтів.

3 огляду на те, що діти із зони конфлікту мають високу частоту ендокринних захворювань, вони потребують щорічних оглядів спеціалістом ендокринологом. 3 позицій можливого фрормування гінекологічної патології необхідно обов'язково консультувати дівчаток у гінеколога при виявленні порушень менструального циклу, часу початку та темпів статевого розвитку.

Комплексний і диференційований підхід до обстеження та спостереження дітей із зони збройного конфлікту, сприятиме своєчасному визначенню можливих порушень з боку різних систем організму і проведенню лікувально-профрілактичних заходів, що, в свою чергу, сприятиме збереженню здоров'я цього контингенту.

Висновки. Одним із пріоритетних напрямків реабілітації, збереження й зміцнення здоров'я 
школярів із зони збройного конфрлікту $€$ використання принципів медико-психологічного супроводу. Алгоритм його дії базується на організаційних, лікувальних, профілактичних заходах на рівні сімейних лікарів, підліткових терапевтів, педіатрів (регулярне проведення лікувально-профрілактичних заходів у межах амбулаторно-стаціонарної допомоги із використанням сучасних лікувально-діагностичних та реабілітаційних технологій із урахуванням індивідуальних особливостей формування функціональних розладів та патологічних станів в умовах дії психоемоційного стресу; інорормаційне забезпечення, організація та контроль за своєчасним проведенням консультативної допомоги хворим у спеціалістів різного профрілю; проведення санітарно-освітньої роботи серед школярів, батьків, поширення знань щодо профрілактики гострої та хронічної соматичної патології, інфекційних, паразитарних захворювань в умовах збройного конолікту; удосконалення особистих знань лікарів стосовно розвитку та особливостей проявів соматичних, нервово-психічних розладів на тлі стресових ситуацій) та у межах психологічної допомоги.

Психологічний супровід дітей та підлітків 3 Донбасу (зони бойових дій) та переселенців має включати в себе такі напрями роботи: психодіагностику емоційного стану дитини; психологічне консультування дітей, яке передбачає індивідуальну та групову психоконсультативну допомогу; психологічне консультування батьків дітей та підлітків; психологічне консультування та психологічна просвіта медичних працівників з питань

\section{Література}

1. Бойкова ВА. Дружинина ТА. Влияние стрессирующих ситуаций на жизненно-смысловые детерминанты личности. Научно-аналитический журнал Вестник Санкт-Петербургского университета государственной противовоздушной обороны. 2012;1:127-132.

2. Буслаева ME, Макарова ВА. Проблемы социальной адаптации детей беженцев и мигрантов в контексте профессиональной подготовки студентов [lssues of social adaptation of of refugee and migrant children in the context of student professional training]. Педагогическое образование в России. 2016;2:155-161.

3. Жуков СВ, Королюк ЕГ. Патогенетическая модель формирования уровня здоровья подростков-вынужденных переселенцев, находящихся в условиях хронического социального стресса [Pathogenetic model of the formation of the health level of adolescent IDPs in conditions of chronic social stress]. Вестник новых медицинских технологий. 2010;XVII(1):71-3.

4. Королюк ЕГ, Жуков СВ, Аронов АБ, Михайлова СИ. Гендерные аспекты метаболической характеристики здоровья детей, находящихся в условиях хронического социального стресса [Gender aspects of metabolic health characteristics of children being under conditions of chronic social stress]. Вестник новых медицинских технологий. 2012;XIX(1):53-54.

5. Bilukha OO, Jayasekaran D, Burton A, Faender G, King'ori J, Amiri M, Leidman E. et al. Nutritional Status of Women and Child Refugees from SyriaJordan, April-May 2014 //MMWR Morb Mortal Wkly Rep. 2014;63(29):638-9.

is_lebets@ukr.net супроводу дітей з психологічними стресовими розладами; психокорекційні заходи для зазначеного контингенту.

Необхідність профрілактики розвитку та прогресування психосоматичних розладів в дітей із зони збройного конфрлікту базується на значній їх частоті та поліморфноості, що потребує мультидисціплінарного підходу, реабілітаційних заходів та нагляду спеціалістами різного профрілю - педіатром, підлітковим терапевтом, сімейними лікарями, за необхідності - кардіоревматологом, гастроентерологом, психіатром, неврологом, гінекологом, ендокринологом та ін.

Перспективи подальших досліджень. Виявлена проблема погіршення стану здоров'я школярів із зони збройного конфрлікту та обгрунтована можливість системного впливу на збереження та зміцнення здоров'я означеного контингенту потребує подальшого вивчення з метою з'ясування ефективності та результативності реалізації запропонованих підходів із запровадженням організаційних, лікувальних, профрілактичних заходів на різних рівнях надання медичної допомоги дітям шкільного віку.

Рекомендації. Запропонований психологічний супровід дітей та підлітків з Донбасу (зони бойових дій) та переселенців, який включає психодіагностику емоційного стану дитини; психологічне консультування дітей, їх родин та психокорекційні заходи доцільно запроваджувати і в інших регіонах країни як ефрективний комплекс реабілітаційних заходів означеного контингенту дитячого населення.

6. Dimitry L. A systematic review on the mental health of children and adolescents in areas ofarmed conflict in the Middle East. Child: care, health and development. 2012;38:153-161.

7. Doocy S, Sirois A, Tileva M, Storey JD, Burnham G, et al. Chronic disease and disability among Iraqi populations displaced in Jordan and Syria. The International journal of health planning and management. 2013;28(1): 1-12.

8. Jeharsae R, Sangthong, R, Wichaidit W, \& Chongsuvivatwong V. Growth and development of children aged 1-5 years in low-intensity armed conflict areas in Southern Thailand: a community-based survey. Conflict and health. 2013;7(1):8.

9. Masten AS. Global Perspectives on Resilience in Children and Youth. Child development. 2014;85:6-20.

10. Mensah FK, Bayer JK, Psych M. [et al.] Early Puberty and Childhood Social and Behavioral Adjustment. Journal of Adolescent Health. 2013;53: 118-24.

11. Noguera RT. The narratives of children in armed conflict: an inference to spirituality and implication to psychological intervention. International Journal of Children's Spirituality. 2013;18:162-72.

12. Wessells MG. Children and Armed Conflict: Introduction and Overview. Peace and Conflict. Journal of Peace Psychology @ 2016 American Psychological Association. 2016;22(3):198-207.

Надійшла 19.02.2020 